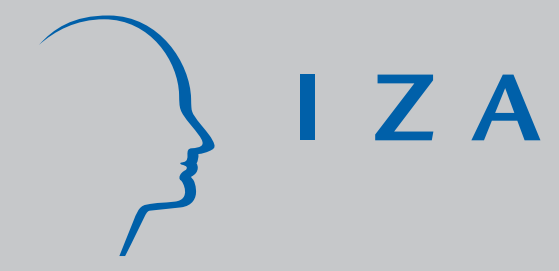

\author{
IZA DP No. 155 \\ The Duration of Immigrants' \\ Unemployment Spells: Evidence \\ from Sweden
}

Jörgen Hansen

May 2000 


\title{
The Duration of Immigrants' Unemployment Spells: Evidence from Sweden
}

\author{
Jörgen Hansen \\ IZA, Bonn
}

Discussion Paper No. 155
May 2000

IZA

P.O. Box 7240

D-53072 Bonn

Germany

Tel.: +49-228-3894-0

Fax: +49-228-3894-210

Email: iza@iza.org

This Discussion Paper is issued within the framework of IZA's research areas Mobility and Flexibility of Labor Markets and the Welfare State and Labor Markets. Any opinions expressed here are those of the author(s) and not those of the institute. Research disseminated by IZA may include views on policy, but the institute itself takes no institutional policy positions.

The Institute for the Study of Labor (IZA) in Bonn is a local and virtual international research center and a place of communication between science, politics and business. IZA is an independent, nonprofit limited liability company (Gesellschaft mit beschränkter Haftung) supported by the Deutsche Post AG. The center is associated with the University of Bonn and offers a stimulating research environment through its research networks, research support, and visitors and doctoral programs. IZA engages in (i) original and internationally competitive research in all fields of labor economics, (ii) development of policy concepts, and (iii) dissemination of research results and concepts to the interested public. The current research program deals with (1) mobility and flexibility of labor markets, (2) internationalization of labor markets and European integration, (3) the welfare state and labor markets, (4) labor markets in transition, (5) the future of work, (6) project evaluation and (7) general labor economics.

IZA Discussion Papers often represent preliminary work and are circulated to encourage discussion. Citation of such a paper should account for its provisional character. 
IZA Discussion Paper No. 155

May 2000

\section{ABSTRACT \\ The Duration of Immigrants' Unemployment Spells: Evidence from Sweden*}

Using a proportional hazard model with multiple exits, this paper analyzes whether immigrants' unemployment spells differ from natives', and if so, how the difference vary with time spent in Sweden and across immigrant cohorts. A unique data set taken from the Swedish unemployment registers is used. The data set covers the period 1991 to 1996, a period of substantial increases in both unemployment rates as well as in immigration. The estimates from the hazard model suggests that a substantial proportion of the observed difference in unemployment spells between natives and immigrants can be explained by differences in accumulated human capital and unemployment compensation. This is especially true regarding the difference between natives and refugees.

JEL Classification: C41, J15, J23, J61, J64

Keywords: Competing risks model, proportional hazard, immigrant assimilation, unemployment duration, unobserved heterogeneity

Jörgen Hansen

IZA

P.O. Box 7240

D-53072 Bonn

Germany

Tel: $+49-2283894223$

Fax: +49-228 3894210

Email: hansen@iza.org

* I would like to thank Christian Belzil, Magnus Lofstrom and seminar participants at IZA for helpful comments. Financial support from The Swedish Council for Work Life Research is gratefully acknowledged. 


\section{Introduction}

During the last two decades, economists have paid considerable attention to the economic assimilation of immigrant workers. A vast majority of previous work have focused on the earnings assimilation of immigrants and little attention has been paid to the determinants of employment and unemployment of immigrants. ${ }^{1}$ Considering that immigrants' use of public transfers, such as unemployment benefits, and their overall economic conditions are of major policy concerns, this is surprising. A few recent articles have studied employment and/or unemployment probabilities and how they differ between natives and immigrants. For example, Chiswick et al, 1997, use four different CPS samples to study employment and unemployment determinants for white native-born and foreign-born men. Their results indicate that recent immigrants have higher unemployment rates, but they drop quite rapidly with time spent in the U.S. McDonald and Worswick, 1997, use Canadian data to assess the unemployment incidence of immigrant men. Their results are in line with Chiswick et al, and suggest that recent immigrants have higher unemployment probabilities than native-born Canadians. Finally, two recent studies based on Danish and Swedish data, respectively, also find support for positive employment assimilation, see Husted et al, 2000; and Bevelander and Skyt Nielsen, 1999.

This paper extends the existing literature on the determinants of unemployment among immigrants. The objective is to determine whether differences in transition rates out of unemployment between natives and immigrants, underlying differences in unemployment rates between the two groups, reflect differences in individual characteristics and economic opportunities or a difference in the two groups' responses to the economic environment. However, the empirical analysis requires access to unique micro-data. Specifically, the data set must not only contain detailed information about unemployment spells, but also, because of the focus on differences between natives and immigrants, it has to be large enough to enable identification of different immigrant groups. This type of micro-data is rare. However, there exist one data set based on information taken from the Swedish unemployment registers, which can be used. The data is collected by the Swedish National Labor Market Administration (AMS) and it provides details about the length of the unemployment spell, as well as some socio-economic background in-

\footnotetext{
${ }^{1}$ For a recent survey of the literature on the economics of immigration, see Borjas, 1994. There exists some recent work on the impact of immigration on native employment opportunities, see Simon et al, 1993; Altonji and Card, 1991; and Winegarden and Khor, 1991.
} 
formation, for persons who registered themselves as unemployed between 1991 and $1996 .^{2}$ Since information about immigrant status is not available in this data set, I matched the data on unemployment spells with a large Swedish panel data set, Longitudinal Individual Data (LINDA). This latter data set contains information on more than 300,000 individuals annually for the period 1991 to 1996, and includes, among other things, information on immigration year and country of origin.

Compared to other countries, Sweden had a very successful unemployment record from the 1960's until the beginning of the 1990's. During this period, the average annual unemployment rate fluctuated between one and four percent. Unemployment rates were kept low, despite an upward trend in other European countries during this period, primarily because of three reasons: active labor market policies, an unemployment insurance system with fixed benefit duration and centralized wage bargaining, see Layard et al, 1991. However, with the recession in the early 1990's, the unemployment rate rose dramatically, from less than two percent in 1990 to about nine percent in 1993. After 1993 it has remained at these, for Sweden, high levels.

Another feature of the Swedish unemployment record during the last three decades is the significant difference in unemployment rates between natives and immigrants. ${ }^{3}$ For instance, the average unemployment rate among the immigrant population was more than twice that of native Swedes during the 1970's and the 1980's. When unemployment rates rose dramatically in Sweden in 1991-1992, the gap between the unemployment rates for immigrants and native Swedes stayed constant, implying unemployment rates of over 20 percent among the immigrant population. For example, in 1990 the average annual unemployment rate was 1.7 percent for the whole male population while it was 4.3 percent for male immigrants. In 1993, these figures were 9.7 percent and 24.0 percent, respectively.

Immigrants in Sweden constitute a heterogeneous group and the composition of immigrants has changed over time, from mainly recruited labor in the 1960's and early 1970's to refugees and tied movers in the 1990's. Data

\footnotetext{
${ }^{2}$ In Sweden, registration at an unemployment office is compulsory for persons who receive unemployment compensation. A large majority of those not entitled to such compensation also register themselves at an office since this is a requirement for having access to labor market programs and other services provided by the offices.

${ }^{3}$ Differences in unemployment rates between natives and immigrants appear to exist in other countries as well. A recent OECD report shows that there exists large differences in unemployment rates between native born and foreign born men in Austria, Belgium, Denmark, France, the Netherlands, Spain and the U.K., see OECD 1998.
} 
on the proportions of males who received any unemployment compensation in 1996 show that this proportion varies substantially across arrival cohorts. Immigrants who arrived in Sweden before 1975 have figures similar to natives, while for recent immigrant cohorts, the difference between natives and immigrants is substantial.

It is quite clear that unemployment has become a serious problem in Sweden, especially unemployment among immigrants. Considering that the inflow of immigrants increased significantly in the 1990's, from about 0.4 percent of the population to about 0.7 percent, and that the unemployment rates have remained high after 1993, despite rapid economic growth, suggests that the unemployment problem is likely to become even more serious in the near future. ${ }^{4}$ This also serves as motivation for this paper and the following questions are of particular interest: (i) Does the exit rate out of unemployment differ in a significant way between immigrants and natives, once differences in observable characteristics are controled for? and (ii) How important are time spent in Sweden and quality differences between different immigrant cohorts for the lenght of immigrants' unemployment spells? ${ }^{5}$ There is very little, if any, empirical evidence that can be used to answer these questions. ${ }^{6}$ For instance, if the longer observed unemployment spells among immigrants are due to differences in observable characteristics, such as accumulated human capital, then provision of labor market training may be profitable. However, if the difference cannot simply be explained by differences in human capital, then the longer spell lenghts among immigrants may be attributed to labor market discrimination or differences in labor market preferences. In this case, provision of additional training may only have a limited impact on immigrants unemployment durations.

There exists several reasons for the observed difference in unemployment rates between natives and immigrants in Sweden. First, some immigrants

\footnotetext{
${ }^{4}$ The proportion of immigrants arriving in Sweden during the 1990's (0.7 percent of the population) is high compared to other Western countries. For example, the corresponding figure for the U.S. was around 0.4 percent in the 1990's.

${ }^{5}$ It should be stressed that the analysis in this paper concentrates on the outflow rates from unemployment, and no attention is paid towards possible differences in the inflow rates. As documented by Bean, 1994, and Layard et al, 1991, European labor markets are characterized ba low inflow rates into unemployment and long average duration of unemployment spells.

${ }^{6}$ Two exceptions are Carling et al, 1996 and 1999, who report a negative and significant effect of being a foreign citizen on the transition rate from unemployment to employment. However, they do not consider differences in the hazard rates across different immigrant cohorts.
} 
(particularly refugees and tied movers) may have difficulties of finding employment upon arrival in Sweden. This could be due to lack of language skills, information about the Swedish labor market etc. However, the employment probabilities may increase with time spent in Sweden which would then yield positive assimilation effects. Secondly, the very generous and universal welfare system that exist in Sweden, combined with a compressed wage structure, may attract a higher proportion of low-skilled immigrants than otherwise similar countries. ${ }^{7}$ It is possible that countries that provide generous welfare programs and a high degree of income security, such as the Scandinavian countries, may attract different types of immigrants than countries with substantially less generous programs, such as the U.S. This form of negative selection of immigrants has recently been discussed by Borjas, 1999. This selection mechanism may be more binding for recent immigrants because of a sharp reduction in wage inequality that took place in the 1970's and 1980's (see Edin and Holmlund, 1995) as well as an expansion of the welfare state during the same period. Thirdly, the composition of the immigrant population may be quite different from the native one. For instance, in Sweden the immigrant population is younger and has less accumulated schooling than the native population. This, combined with observed pattern of higher unemployment rates among younger workers and among low-skilled workers, may also explain differences in observed unemployment rates between natives and immigrants. Consequently, it is reasonable to expect differences in unemployment rates between natives and immigrants because of assimilation effects and immigrant cohort effects but also because of differences in individual characteristics.

The main result in this paper suggests that a large proportion of the observed difference in unemployment spell lenghts between natives and immigrants, especially between natives and refugee immigrants, can be explained by differences in accumulated human capital and unemployment compensation. For example, the estimates from the hazard model imply that the expected duration of an unemployment spell, with exit to employment, for an average refugee is 167 days, while it is 81 days for a representative native. In a simulation where I assigned the average native worker's set of observable characteristics to a refugee worker, the expected duration decreased to 102 days. This means that, in this stylized example, over 75 percent of the gap in the lenght of unemployment spells between native Swedes and refugees

\footnotetext{
${ }^{7}$ OECD reports that the immigrant to native unemployment ratio is very high (it varies between 1.6 and 2.8) in Denmark, the Netherlands and Sweden. A common feature of these countries is that they provide generous benefit payments to immigrants, see Husted et al, 2000; van Ours and Veenman, 1999; and Hansen and Lofstrom, 1999.
} 
can be attributed to differences in observable characteristics, and less than 25 percent to either differences in unobserved preferences or labor market discrimination.

The paper is organized in the following way. In Sections 2 and 3, I provide some background information about immigration into Sweden and about immigrants' performance in the Swedish labor market. Section 4 describes the unemployment insurance system in Sweden while in Section 5, the data and the variables used are described. The econometric model is presented in Section 6 and the results are discussed in Section 7. Finally, Section 8 concludes the paper.

\section{Immigration into Sweden since World-War II}

The inflow of immigrants to Sweden has undergone a number of changes during the last six decades. Figure 1 shows annual immigration to Sweden from 1940 to 1998, both in terms of actual immigrant inflow and inflow expressed as proportion of the population in the corresponding year. Because of limited population growth during this period, these two measures closely coincide most of the years. Overall, annual immigration has amounted to about 0.4 percent of the population, but notably higher during the 1990's. This is a relatively high proportion compared to other Western countries. For example, the corresponding figure for the United States was around 0.3 percent in the 1980's and 0.4 percent in the 1990's. Naturally, the large inflow of immigrants has also changed the composition of the population in Sweden. In 1991, about 10 percent of the Swedish population were born outside Sweden. Again, this is a quite high figure compared to other countries. For example, in 1991 the share of foreigners in the population was 7.9 percent in the US and 6.9 percent in Germany. The average for the European Union was 3.0 percent (Zimmermann, 1995).

The variation in the inflow of immigrants is evident from Figure 1. In fact, three different phases where immigration increased substantially between 1940 and 1998 can be identified; in the immediate years following World War II, in the late 1960's and early 1970's, and finally in the late 1980's and early 1990's. In the period around World War II, there was a substantial inflow of refugees to Sweden, especially from the Nordic countries. During the following 20 years, there was an annual inflow of about 25,000 people (corresponding to about 0.35 percent of the population). From the 
mid 1960's until the early 1970's, there was a large increase in immigration to Sweden. During these years, the annual inflow of immigrants amounted to about 1 percent of the population. The reason for the increase in immigration was active recruitment of labor conducted by the booming Swedish industry, which faced a shortage of unskilled labor during this period. A large fraction (about 60 percent) of the recruited labor force came from the Nordic countries (especially Finland). In the early 1970's, this recruitment stopped, and the number of immigrants dropped to levels slightly above those that prevailed in the 1950's. The third big increase in the inflow of immigrants took place in the late 1980's and early 1990's. The main reasons for the rise in immigration during this period were the war between Iran and Iraq and the political instability in the Balkans. The average inflow during this period was around 0.7 percent of the population.

The reasons people immigrate to Sweden have changed substantially during the post-war period. In principle, immigrants can be grouped into three categories depending on the reasons for immigration: economic migrants (due to the recruitment of labor), tied movers (i.e. family ties) and refugees. In the late 1940's, a large fraction of the immigrants arrived in Sweden as refugees. However, in the period from 1950 to 1970, most of the immigrants were recruited by the Swedish industry or they arrived because of family ties. From 1970 and onwards, the proportion of immigrants arriving as refugees has increased significantly, from less than 10 percent of the immigrant inflow in 1970 to about 70 percent in the early 1990's. In 1994, this proportion dropped from 70 percent to about 50 percent, mostly due to the improved conditions in the Balkan countries.

\section{Immigrants' Performance in the Swedish Labor Market}

It is well known that immigrants' performance in the labor market, in general, is less succesful than that of natives, even if there exists evidence on assimilation effects. This holds true both in terms of wages and employment probabilities. In Figure 2, I present average annual unemployment rates in Sweden between 1984 and 1998, both for the entire Swedish population and for foreign citizens only. Throughout the whole period, the unemployment rates among immigrants (foreign citizens) are about twice that of the whole population. This is also true for the period after the early 1990's when overall unemployment rose dramatically, from about two percent in 1990 to almost 10 percent in 1993. 
Even if Figure 2 clearly shows the difference in unemployment rates between natives and immigrants in Sweden, it does not show the variation in unemployment rates that may exist within the immigrant population. As such, it cannot tell us whether the increase in unemployment among immigrants is due to increased unemployment probabilities for all immigrant groups or if the increase is due to a change in the composition of immigrants.

The information in Table 1 displays the proportion of natives, non-refugee immigrants and refugee immigrants that received any unemployment compensation between 1990 and 1996. The differences between the numbers in Table 1 and the unemployment rates in Figure 2 are partly due to the fact that persons being unemployed but engaged in labor market programs are not counted as unemployed in Figure $2 .{ }^{8}$ As can be seen from Table 1, this group of unemployed workers constitutes a significant share of the population and it has been growing since 1990. For example, in 1990 about two percent of the native labor force was defined as unemployed while about six percent received unemployment compensation or welfare payments. In 1996, these figures are about eight percent and about 17 percent, respectively. Hansen and Lofstrom, 1999, reports native welfare participation rates of 3.2 percent in 1990 and 4.7 percent in 1996. This implies that about one percent of the labor force was engaged in some kind of labor market program in 1990 and that this figure had increased to about 12 percent in 1996.

Table 1 shows that the proportion of natives that received any form of unemployment compensation increased by 10.7 percentage points between 1990 and 1996. This corresponds to an increase of 181 percent. For immigrants, the absolute increase was similar to the one for natives, but the relative increase was smaller. This suggests that despite large absolute increases in unemployment rates among immigrants, the unemployment rates among immigrants still decreased relative to natives for all immigrant groups during this period. Further, it also suggests that the sharper increase in unemployment rates for immigrants compared to natives, as shown in Figure 2, can be attributed to higher rates among recent immigrants. The figures in Table 1 show that there exist substantial variations in unemployment rates across arrival cohorts and country of origin. Immigrants who arrived in the 1960's and early 1970's show significantly lower unemployment rates than immigrants who arrived after the mid 1980's. Further, unemployment rates

\footnotetext{
${ }^{8}$ Further, since a substantial proportion of immigrants are not entitled to unemployment compensation and have to rely on welfare, the entries in Table 1 consists of the proportion receiving either unemployment compensation or welfare payments. For more details on welfare participation in Sweden during this period, see Hansen and Lofstrom, 1999.
} 
appear to increase monotonically with arrival year. This may suggest the existence of assimilation effects in the sense that unemployment rates are reduced with time spent in Sweden.

\section{Unemployment Insurance in Sweden}

The Swedish unemployment insurance system consists of two parts: unemployment benefits (Arbetslöshetskassa, UB) and unemployment assistance (Kontant arbetsmarknadsstöd, UA). The former is run by the trade unions at the industry level, but is to a large extent tax financed. In 1990, the coverage was slightly less than 80 percent of the labor force. To be entitled to compensation from UB, an individual must actively search for a job at a public employment office. Also, to remain eligible, any "suitable" offer must be accepted. Refusal to accept an offer may lead to expulsion from compensation. Registration at the public employment office is required for persons who receive unemployment compensation. ${ }^{9}$ In addition to this, there is a "membership condition" and a "work condition" that have to be met. The claimant must have paid membership fees to the UB fund for the last 12 months and he must have been working for at least 75 days distributed over at least four months during the 12 months preceding the current unemployment spell. The latter two conditions imply that many of the new entrants in the labor market, such as young workers and immigrants, are not entiteled to compensation from UB.

Workers who do not meet the membership condition for receiving UB may be entitled to compensation from UA. However, there exists a similar work requirement for receiving UA as for receiving UB. As opposed to UB, young workers who have finished at least one year of school in excess of the nine compulsary years are entitled to UA. They must however search for a job at a public employment office to be entitled for compensation.

UB fund members are entitled to compensation for 300 (work) days. ${ }^{10}$ Until 1993, the replacement rate was 90 percent up to a maximum level determined by the government. In July 1993, the replacement rate was changed to 80 percent. UA is substantially less generous than UB, both in terms of benefit duration and compensation levels. Maximum benefit duration is half

\footnotetext{
${ }^{9}$ For persons that are not entitled to compensation, registration is optional. However, to get access to all the services provided by the employment office (including labor market programs) registration is required and therefore a large majority of the unemployed do register at the agencies.

${ }^{10}$ For workers over the age of 55 , the benefit duration is 450 days.
} 
that of UB, 150 work days. ${ }^{11}$ Also the level of compensation is significantly lower in UA compared to UB. In 1990, average compensation levels in UA was 174 SEK compared to 402 SEK for UB, see Forslund and Krueger, 1997.

\section{Data}

In this paper I use data on unemployed persons in Sweden who were registered at the public employment agency anytime between January 1991 and December 1996. The data contain information on the duration of the unem-

ployment spell, unemployment compensation, as well as on duration of the benefit period. ${ }^{12}$ In order to obtain information about immigrant status (i.e. country of origin and time of arrival in Sweden), the data on unemployment spells were matched with a large individual panel data set (Longitudinal Individual Data, LINDA). A person is defined as an immigrant if he was born abroad, and as a refugee if he was born in a refugee country, as defined by the Swedish Immigration Board, or in a sub-Saharan country.

The duration of the unemployment spells are measured in days, from the time of registration at the unemployment office until the end of the first (unemployment) spell. Upon registration at the unemployment office, background information, such as age, education and previous work experience, are recorded. Based on the persons work history, his level of compensation and benefit period are also determined. Before any selections were made, the sample contained information on 92,165 individuals. I excluded females, men older than 55 and anyone with a disability to work. The final sample after these exclusions consists of 32,152 unemployed men (49,046 spells).

Characteristics for the individuals included in the sample are shown in Table 2. The entries in the first column refers to native Swedes, while those in the second and third columns refer to non-refugee and refugee immigrants, respectively. As shown, 58 percent of the natives have a high school degree, while 14 percent have a college degree. For immigrants, the figures are 42 and 17 percent (non-refugees) and 30 and 21 perent (refugees). A majority of natives and non-refugee immigrants have both some training and work experience in the jobs they are applying for (these jobs are from here on referred to as applied jobs). For refugee immigrants however, the opposite holds. One reason for this may be that previous work history aqcuired in the

\footnotetext{
${ }^{11}$ For workers over the age of 55 , the benefit duration is 300 days, and 450 days for those over the age of 60 .

${ }^{12}$ Carling et al, 1999, provides a detailed description of the data set.
} 
country of origin is country specific and less attractive to Swedish employers. The immigrants in the sample arrived in Sweden at a fairly young age, in the middle of their 20's for both groups. Non-refugee immigrants have, on average, been in Sweden for a longer time.

Concerning the duration of the unemployment spells, there exist large differences between the three groups. For natives, the average duration, with exit to employment, is 128 days, while it is 158 days for non-refugee immigrants and 171 days for refugee immigrants. For all three groups, the average unemployment spell is longer for those who exit to labor market programs compared to those who exit to employment. Further, the difference between natives and refugees is smaller than in the case of exits to employment. Finally, a large fraction of immigrants are unemployed for more than half a year (36 percent for non-refugees and 38 percent for refugees).

In Tables 3-5, I present transitions out of unemployment for each group. As mentioned above, I distinguish between three different destination states: employment (including self-employment), participation in labor market programs and exit out of the labor force. In Table 3, information for natives are presented. It shows that 54.2 percent exit to employment, 22.7 percent to labor market programs and 7.1 percent drop out of the labor force. The remaining 16 percent consists of right censored observations. ${ }^{13}$ It is clear from Table 3 that exits to employment increase with age and also that having traing and/or extensive work experience in applied jobs increase the chance of exiting to employment. Further, over 26 percent of the very young persons (below 20) drop out of the labor force, presumably to return to school. Finally, labor market programs seems to be primarily targeted towards workers with a college degree and workers with no previous work experience in applied jobs. Tables 4 and 5 shows that the proportion of immigrants who exit from unemployment to regular employment is substantially smaller than for natives. Further, more immigrants than natives exit to labor market programs, drop out of the labor force and are right censored. Despite these differences, the age and human capital pattern that were found for natives are also found for immigrants.

\section{Empirical Specification}

In this paper I specify and estimate a competing risks model controlling for unobserved heterogeneity. I follow the dominating strategy in previous

\footnotetext{
${ }^{13} \mathrm{~A}$ portion of the right censored observations were censored because the unemployment office lost contact with the persons.
} 
studies and assume independence between the risks, see for instance Carling et al, 1996 and 1999, and Narendranathan and Stewart, 1993. The individual may remain unemployed at time $t$ and continue to search because of two reasons, either there were no job offers arriving during this time interval or the offers were not acceptable. If an acceptable offers arrives, unemployment is terminated. However, accepting a job offer is not the only way to leave unemployment. The two other escape routes out of unemployment considered in this paper are to participate in labor market programs or to leave the labor force.

In a single risk model, the risk of leaving unemployment can be described by the hazard rate, $h(t \mid x ; \Theta)$, which equals the probability of leaving the unemployment state in the next infinitesimal period, conditional that the individual is still unemployed. Formally, the hazard rate can be defined as:

$$
h(t \mid x ; \Theta)=\lim _{\Delta \rightarrow 0} \frac{\operatorname{Pr}(t \leq T \leq t+\Delta \mid T \geq t)}{\Delta}=\frac{f(t \mid x ; \Theta)}{1-F(t \mid x ; \Theta)}
$$

where $f(t \mid x ; \Theta)$ is the density function of $t, 1-F(t \mid x ; \Theta)$ equals the survivor function $(S(t \mid x ; \Theta)), x$ is a vector of individual specific observable characteristics and $\Theta$ is a vector of parameters.

A popular specification of the hazard function is the proportional hazard function, where the hazard rate can be decomposed into two parts; the baseline hazard $\left(h_{0}(t)\right)$ and an individual specific component, $\lambda(x ; \theta)$. Formally,

$$
h(t \mid x ; \Theta)=h_{0}(t) \lambda(x ; \theta)
$$

where a flexible way of specifying $h_{0}(t)$ which also allow for duration dependence is to assume that the baseline hazard is piecewise constant (see Lancaster, 1990). This implies that for the baseline hazard, the unemployment spell can be divided into $K$ intervals:

$$
\begin{aligned}
& h_{0}(t)=\gamma_{1} \text { if } \quad 0 \leq t \leq c_{1} \\
& \gamma_{2} \quad \text { if } \quad c_{1}<t \leq c_{2} \\
& \vdots \quad \vdots \quad \vdots \\
& \gamma_{K} \quad \text { if } \quad c_{K-1}<t<\infty
\end{aligned}
$$

where $\gamma_{k}$ are parameters to be estimated, the $c_{k}^{\prime} s$ are points in time and $0<c_{1}<c_{2}<\ldots<c_{K-1}<\infty$. Assuming that $\gamma_{k}=\exp \left(\eta_{k}\right)$ and that $\lambda(x ; \theta)=\exp \left(x^{\prime} \theta\right)$, the hazard function can be written as: 


$$
h(t \mid x ; \Theta)=\exp \left(d_{k} \eta_{k}\right) \lambda(x ; \theta)=\exp \left(d_{k} \eta_{k}+x^{\prime} \theta\right)
$$

where $d_{k}$ equals one if $t$ falls within the interval $\left(c_{k-1}, c_{k}\right]$, and equal to zero otherwise. Assuming only time-invariant covariates in $x$, the integrated hazard is:

$$
\Lambda(t \mid x ; \Theta)=\lambda(x ; \theta)\left[\sum_{l=0}^{k} b_{l} \gamma_{l}+\left(t-c_{k}\right) \gamma_{k+1}\right]
$$

where $b_{l}=c_{l}-c_{l-1}, c_{k}<t \leq c_{k+1}$ and $k=0,1, \ldots, K-1$. The likelihood contribution of a given individual, $i$, can now be written as:

$$
L_{i}^{1}(\Theta)=h_{i}(t \mid x ; \Theta)^{c_{i}} \exp \left[-\Lambda_{i}(t \mid x ; \Theta)\right]
$$

where $c_{i}$ is a binary variable that is equal to one if the observation is uncensored and it is equal to zero otherwise.

In a competing risks framework, the hazard rate from unemployment equals the sum of $J$ different hazard rates where $J$ denote the number of different risks, or exit routes, that exists. The observed unemployment duration can be written as:

$$
t=\min \left(t_{1}, t_{2}, \ldots, t_{J}\right)
$$

and the individual contribution to the likelihood function is now

$$
L_{i}^{2}(\Theta)=\prod_{j=1}^{J}\left\{h_{i}^{j}(t \mid x ; \Theta)^{c_{i j}} \exp \left[-\Lambda_{i}^{j}(t \mid x ; \Theta)\right]\right\}
$$

where $c_{i j}$ is a binary variable that equals one if individual $i$ exits to state $j$ it equals to zero otherwise. Because of the independence assumption between the risks, estimation of the $J$ durations can be done seperately and the contribution of an observed exit to destination $m \neq j$ to the likelihood in (4) is the same as that of a censored observation in (3).

The likelihood functions in (3) and (4) are only correct as long as all individual heterogeneity is captured by the covariates, $x$. However, there may 
exist unobserved factors that influence the exit rates out of unemployment. In such cases, the likelihood functions described above are misspecified and the estimated hazard rates are biased. Assuming a multiplicative form of the unobserved heterogeneity, the hazard rate is:

$$
h^{j *}(t \mid x ; \Theta, \mu)=h_{i}^{j}(t \mid x ; \Theta) \mu^{j}
$$

where $\mu^{j}$ is a random variable, assumed to be independent of $x$, defined on $\Re^{+}$, and with a cumulative distribution function, $H\left(\mu^{j}\right)$. The individual contribution to the likelihood function, for risk $j$, is obtained by conditioning on the unobserved $\mu^{j}$ and then integrating over its distribution:

$$
L_{i}^{j}(\Theta)=\int_{\Re^{+}}\left(h_{i}^{j}(t \mid x ; \Theta) \mu^{j}\right)^{c_{i j}} \exp \left[-\Lambda_{i}^{j}(t \mid x ; \Theta) \mu^{j}\right] d H\left(\mu^{j}\right)
$$

To implement this approach, the distribution function, $H\left(\mu^{j}\right)$, must be specified. ${ }^{14}$ A convenient and commonly used distribution for $\mu^{j}$ is the gamma distribution. However, as argued by Heckman and Singer, 1984, the parameter estimates may be very sensitive towards distributional assumptions. They instead suggested to use a non-parametric distribution for $\mu^{j}$. Specifically, assume that the probability distribution of $\mu^{j}$ can be approximated by a discrete distribution with a finite number $(M)$ of support points. In this case, the integration in (6) is replaced by a summation over the number of supports for the distribution of $\mu^{j}$. Associated with each support point is a probability, $p_{m}$, where $p_{m} \geq 0$ and $\sum_{m=1}^{M} p_{m}=1$.

\section{Empirical Results}

The results from estimation of the likelihood function in (6) are presented in Table 6. To estimate the likelihood function I fix the number of support points by setting $M$ equal to two in all estimations. To be as flexible as possible with regards to assimilation effects, I specified fully interacted versions of the hazard functions giving separate effects of the covariates for natives, non-refugee immigrants and refugee immigrants. The estimates of the baseline hazard and the indicators for when the unemployment spell started are not reported in Table 6 to save space. ${ }^{15}$ For exits to employment and out-of

\footnotetext{
${ }^{14}$ Note that I have used the independence assumption discussed above which allow me to estimate each of the $J$ likelihood functions seperately.

${ }^{15}$ The estimates are avaible upon request.
} 
the labor force, the baseline hazard appears to be constant. For exits to labor market programs, however, the results suggest positive duration dependence.

\subsection{Employment}

In the first two coulmns of Table 6, I present results from the competing risks model with exits to employment. The results suggests that the hazard rate decrease with age, both for natives and immigrants. The effect of formal education on the hazard rate is mixed. For natives, there is a significant and positive effect of having a high school degree and having training in applied jobs while there is a negative, significant effect of having a college degree. This result was also suggested in Table 3, which showed higher proportions of men with high school or less exiting unemployment for employment. The estimates in Table 6 indicate that the observed difference in Table 3 prevails when controls for work experience and unemployment benefits are included. The effect of education and previous work experience for immigrants suggests that there is a positive, but small, effect of a college degree on the exit rate to employment. Having training and work experience in applied jobs has a positive effect on the exit rate for non-refugees, although the effect is smaller than for natives, and it is even smaller for refugees. Altogether, the estimates suggests that there are only marginally different.effects of human capital on the hazard rate for natives and immigrants.

Concerning the effects of the remaining covariates, the estimates suggest higher exit rates for married men but again with smaller effects for immigrants. Further, the results also imply higher exit rates for those with higher unemployment compensation. ${ }^{16}$ This results contrast much of what has been reported in previous literature who generally find that higher benefit levels decrease the exit rate. However, as shown by Mortensen, 1977, and Burdett, 1979, when the benefit levels depends on previous work experience and salaries, higher benefit levels may actually increase the exit rate to employment.

The two main research questions posed in the introduction were whether the exit rate out of unemployment differ between natives and immigrants, and if the exit rates for immigrants vary with time spent in Sweden and the importance of quality differences between immigrant cohorts for the exit rates. Considering the latter question first, the estimates in Table 6 provides

\footnotetext{
${ }^{16} \mathrm{I}$ do not allow the hazard rate to vary as benefit exhaustion is approached. Carling et al, 1996, estimate these effects using Swedish data and find only weak evidence of such a pattern.
} 
some weak support for the hypothesis that there exists significant cohort differences in the hazard rates. Everything else equal, the estimates imply that immigrants who arrived in Sweden in the late 1960's and in the 1970's have higher hazard rates than immigrants who arrived in the late 1980 ' or in the 1990's. The estimates further suggests that the effects are even stronger for refugee immigrants. However, these estimates are not significant at conventional levels. Regarding the effect of time spent in Sweden, the estimates are negative and insignificant, suggesting that the hazard rate does not change with time spent in Sweden. Overall, the estimates for exits to employment provides only weak support for differences in waiting times between natives and immigrants. This is also documented in Table 7, where I present expected duration of unemployment spells, by destination, for different representative agents. In the first column, expected duration of the spell with exits to employment are reported. For an average native man, expected duration equals 81 days. For average immigrant men, the figures are 108 and 167 days for non-refugees and refugees, respectivly. However, when I assign average native characteristics to the immigrant men, their expected duration falls, especially for refugees. For instance, over 75 percent of the gap in the expected lenght of unemployment spells between a native Swede and a refugee can be attributed to differences in observable characteristics, and less than 25 percent to either differences in unobserved preferences or labor market discrimination. For non-refugees, the proportion of the gap that can be attributed to differences in observables is smaller, close to 40 percent. Hence, the observed difference between natives, non-refugee immigrants and refugee immigrants that was documented in Table 2 seems to be, to a large extent, driven by differences in accumulated human capital and unemployment compensation.

\subsection{Labor Market Programs}

The results from the competing risks model with exits to labor market programs are shown in columns three and four of Table 6 . As for the case with exits to employment, the hazard rate decrease with age, both for natives and immigrants. The effect of formal education on the hazard rate is positive and significant. This result may suggest that many of the labor market programs are targeted for educated workers. It may also indicate that educated and unemployed workers are more likely to apply for participation in these types of programs. However, having training and work experience in applied jobs has a significant and negative effect on the exit rate. As was shown above, this type of workers have a much higher probability of leaving unemployment for employmment rather than entering a labor market program. The results 
for immigrants are similar to those of natives, except that those with higher education have lower probabilities of exiting to labor market programs than natives. Further, the coefficient for years since migration is significant and negative for refugees, suggesting negative assimilation. Considering the huge inflow of refugees to Sweden in the 1990's, and that these refugees possessed less skills than older refugee cohorts, the results may simply reflect priorities made by the Swedish employment offices to get recent refugees into traing relatively fast. ${ }^{17}$ The entries in Table 7 illustrates this point further. The result show that a refugee with observable characteristics that are similar to a representative native male has to wait longer to get into a labor market program than a representative male refugee. One should note, however, that the waiting time is still longer for a refugee man compared to a native Swede.

Concerning the effects of the remaining covariates, the estimates suggest higher exit rates for married men but again with smaller effects for immigrants. Further, the results also imply lower exit rates for those with higher unemployment compensation. Altogether, and similar to the case for exits to employment, the observed difference in the duration of unemployment spells, conditioning on exit to a labor market program, between natives and immigrants that was shown in Table 2 seems to be explained by differences in accumulated human capital and unemployment compensation.

\subsection{Out-of the Labor Force}

In the last two coulmns of Table 6 the results from the competing risks model with exits to out-of the labor force are shown. As for the case with exits to employment and to labor market programs, the hazard rate decrease with age, both for natives and immigrants, but less so for immigrants. The effect of formal education on the hazard rate is negative and significant. This means that unemployed workers who have acquired higher education have lower probabilities of leaving the labor force. This result also holds for workers who possess some training in applied jobs or who have previous work experience. Similar to the results for exit to labor market programs, the estimates suggest lower exit rates for those with higher unemployment compensation. However, as opposed to exits to employment and labor market programs, immigrants haver lower waiting times than natives for exits to the out-of the labor force state. This is also illustrated in the last column of Table 7 , which clearly shows a significant difference in unemployment spells between natives and refugee immigrants.

\footnotetext{
${ }^{17}$ In the data, recent refugees (arriving in Sweden after 1989) have less accumulated schooling, training in applied jobs and work experience than older refugee cohorts.
} 


\section{Conclusions}

Using a proportional hazard model with multiple exits, this paper analyzes the duration of immigrants' unemployment spells. A unique data set taken from the Swedish unemployment registers, collected by the Swedish National Labor Market Administration (AMS), is used. The data set covers the period 1991 to 1996, a period of substantial increases in both unemployment rates and immigration. The paper set out to answer two specific questions regarding immigrants' unemployment experience in Sweden: (i) How does the exit rate out of unemployment vary between natives and immigrants? and (ii) Are there any differences in exit rates across different immigrant cohorts? The estimates from the hazard model suggests that a substantial fraction of the observed difference in unemployment spell lenghts between natives and immigrants can be attributed to differences in observable characteristics, especially accumulated human capital and labor market attachment. Further, the results suggests only weak support for the hypothesis that the lenght of unemployment spells vary across immigrant cohorts.

Apart from estimating a proportional hazard model, the paper also documents some interesting characteristics of the Swedish labor market during the first half of the 1990's. It shows that the increase in unemployment rate was in fact higher among natives than immigrants, and that the sharper increase in the immigrant unemployment rate was due to a change in the composition of immigrants. Nonetheless, despite the slower increase in the unemployment rate for immigrants compared to natives, it remains very high among immigrants. Although this paper only focus on one component of the unemployment rate, the outflow rate, the results are important. They indicate that a substantial fraction of the gap in the outflow rates, and in the unemployment rate, can be explained by differences in observable characteristics. This suggests that even more resources needs to be allocated to increase the labor market attachment among immigrants. As mentioned before, this paper pay no attention to the inflow rates into unemployment, and how these inflow rates may vary between natives and immigrants. This is an area of research that has not attracted much attention and suggests an avenue for future research. 


\section{References}

[1] Altonji, Joseph G. and David Card, 1991, "The Effects of Immigration on the Labor Market Outcomes of Less-Skilled Natives," In John M. Abowd and Richard B. Freeman, eds., Immigration, Trade, and the Labor Market, Chicago, The University of Chicago Press, pp. 201-234.

[2] Bean, Charles R., 1994, "European Unemployment: A Survey," Journal of Economic Literature, Vol. 32, No. 2, pp. 573-619.

[3] Bevelander, Pieter and Helena Skyt Nielsen, 1999, "Declining Employment Assimilation of Immigrants in Sweden: Observed or Unobserved Characteristics?," CEPR Discussion Paper No. 2132, CEPR, London, United Kingdom.

[4] Borjas, George J., 1994, "The Economics of Immigration," Journal of Economic Literature, Vol. 32, No. 4, pp. 1667-1717.

[5] Borjas, George J., 1999, "Immigration and Welfare Magnets," Journal of Labor Economics, Vol. 17, No. 4, pp. 607-637.

[6] Burdett, Kenneth, 1979, "Unemployment Insurance Payments as a Search Subsidy: A Theoretical Analysis," Economic Inquiry, Vol. 17, No. 3, 333-342.

[7] Carling, Kenneth, Per-Anders Edin, Anders Harkman and Bertil Holmlund, 1996, "Unemployment Duration, Unemployment Benefits, and Labor Market Programs in Sweden," Journal of Public Economics, Vol. 59, No. 3, pp. 313-334.

[8] Carling, Kenneth, Bertil Holmlund and Altin Vejsiu, 1999, "Do Benefit Cuts Boost Job Findings? Swedish Evidence from the 1990s," IFAU Working Paper No. 8, IFAU, Uppsala, Sweden.

[9] Chiswick, Barry R., Yinon Cohen and Tzippi Zach, 1997, "The Labor Market Status of Immigrants: Effects of the Unemployment Rate at Arrival and Duration of Residence," Industrial and Labor Relations Review, Vol. 50, No. 2 (January), pp. 289-303.

[10] Edin, Per-Anders and Bertil Holmlund, 1995, "The Swedish Wage Structure: The Rise and Fall of Solidarity Wage Policy?," In Richard B. Freeman and Lawrence F. Katz, eds., Differences and Changes in Wage Structures, Chicago and London, The University of Chicago Press, pp. 307-343. 
[11] Forslund, Anders and Alan B. Krueger, 1997, "An Evaluation of the Swedish Active Labor Market Policy: New and Received Wisdom," In Richard B. Freeman, Robert Topel and Birgitta Swedenborg, eds., The Welfare State in Transition: Reforming the Swedish Model, Chicago, The University of Chicago Press, pp. 267-298.

[12] Hansen, Jörgen and Magnus Lofstrom, 1999, "Immigrant Assimilation and Welfare Participation: Do Immigrants Assimilate Into or Out-of Welfare?," IZA Discussion Paper No. 100, IZA, Bonn, Germany.

[13] Heckman, James J. and Burton L. Singer, 1984, "A Method for Minimizing the Impact of Distributional Assumptions in Econometric Models for Duration Data," Econometrica, Vol. 52, No. 2, pp. 271-320.

[14] Husted, Leif, Helena Skyt Nielsen, Michael Rosholm and Nina Smith, 2000, "Employment and Wage Assimilation of Male First Generation Immigrants in Denmark," IZA Discussion Paper No. 101, IZA, Bonn, Germany.

[15] Lancaster, Tony, 1990, The Econometric Analysis of Transition Data, Econometric Society Monographs, Cambridge, Cambridge University Press.

[16] Layard, Richard, Stephen Nickell and Richard Jackman, 1991, Unemployment: Macroeconomic Performance and the Labour Market, Oxford, Oxford University Press.

[17] McDonald, James T. and Christopher Worswick, 1997, "Unemployment Incidence of Immigrant Men in Canada," Canadian Public Policy, Vol. 23, No. 4, pp. 353-373.

[18] Mortensen, Dale T., 1977, "Unemployment Insurance and Job Search Decisions," Industrial and Labor Relations Review, Vol. 30, No. 3, pp. 505-517.

[19] Narendranathan, Wiji and Mark B. Stewart, 1993, "Modelling the Probability of Leaving Unemployment: Competing Risks Models with Flexible Base-line Hazards," Applied Statistics, Vol. 42, No. 1, pp. 63-83.

[20] OECD, 1998, Trends in International Migration: Annual Report, Paris.

[21] van Ours, Jan C. and Justus Veenman, 1999, "The Netherlands: Old Emigrants - Young Immigrant Country," IZA Discussion Paper No. 80, IZA, Bonn, Germany. 
[22] Simon, Julian L., Stephen Moore and Richard Sullivan, 1993, "The Effect of Immigration on Aggregate Native Unemployment: An AcrossCity Estimation," Journal of Labor Research, Vol. 14, No. 3, pp. 299316.

[23] Winegarden, Calman R. and Lay Boon Khor, 1991, "Undocumented Immigration and Unemployment of U.S. Youth and Minority Workers: Econometric Evidence," Review of Economics and Statistics, Vol. 73, No. 1, pp. 105-112.

[24] Zimmermann, Klaus F., 1995, "Tackling the European Migration Problem," Journal of Economic Perspectives, Vol. 9, No. 2, pp. 45-62. 
Table 1. Percent receiving UI benefits in Sweden 1990 and 1996. By immigration year. Males aged 25-55.

\begin{tabular}{lcccc} 
& & & $\begin{array}{c}\text { Difference in } \\
\text { Percentage Points } \\
\mathbf{1 9 9 0 - 1 9 9 6}\end{array}$ & $\begin{array}{c}\text { Percentage } \\
\text { Difference } \\
\mathbf{1 9 9 0 - 1 9 9 6}\end{array}$ \\
\hline Native Swedes & $\mathbf{1 9 9 0}$ & $\mathbf{1 9 9 6}$ & & \\
& 5.9 & 16.6 & 10.7 & 181 \\
Non-Refugees Immigrated in: & & & & \\
1968-1974 & 10.5 & 21.2 & 10.7 & 102 \\
$1975-1979$ & 15.8 & 25.8 & 10.0 & 63 \\
$1980-1984$ & 17.8 & 26.8 & 9.0 & 51 \\
$1985-1989$ & 18.6 & 32.9 & 14.3 & 77 \\
$1990-$ & N.A. & 36.5 & N.A. & N.A. \\
& & & & \\
Refugees Immigrated in: & & & & 85 \\
$1968-1974$ & 12.9 & 23.9 & 11.0 & 54 \\
$1975-1979$ & 18.6 & 28.7 & 10.1 & 48 \\
$1980-1984$ & 24.6 & 36.4 & 11.8 & 26 \\
$1985-1989$ & 43.8 & 55.1 & 11.3 & N.A. \\
$1990-$ & N.A. & 75.8 & N.A. & \\
\hline
\end{tabular}

Sources: LINDA 1990 and 1996. 
Table 2. Descriptive Statistics, by immigration status.

\begin{tabular}{|c|c|c|c|}
\hline Variable & Natives & $\begin{array}{r}\text { Immigrants } \\
\text { Non-Refugees }\end{array}$ & $\begin{array}{r}\text { Immigrants } \\
\text { Refugees }\end{array}$ \\
\hline \multicolumn{4}{|l|}{ Age: } \\
\hline Age & 33 & 35 & 34 \\
\hline \multicolumn{4}{|l|}{ Education and Training: } \\
\hline High school & 0.58 & 0.42 & 0.30 \\
\hline College & 0.14 & 0.17 & 0.21 \\
\hline Has training in applied jobs & 0.66 & 0.55 & 0.4 \\
\hline Some work experience in applied jobs & 0.23 & 0.26 & 0.31 \\
\hline Extensive work experience in applied jobs & 0.58 & 0.52 & 0.33 \\
\hline \multicolumn{4}{|l|}{ Immigrant Status: } \\
\hline Arrived 1968-1974 & & 0.25 & 0.03 \\
\hline Arrived 1975-1979 & & 0.17 & 0.09 \\
\hline Arrived 1980-1984 & & 0.11 & 0.12 \\
\hline Arrived 1985-1989 & & 0.20 & 0.39 \\
\hline Arrived 1990- & & 0.27 & 0.38 \\
\hline Age at migration & & 24 & 28 \\
\hline Years since migration & & 11 & 6 \\
\hline \multicolumn{4}{|l|}{ Duration of unemployment spell (Days): } \\
\hline Exits to Employment & 128 & 158 & 171 \\
\hline Exits to Labor Market Programs & 158 & 178 & 177 \\
\hline Exits to Out-of the Labor Force & 142 & 158 & 193 \\
\hline Proportion with Duration Longer than 180 Days & 0.27 & 0.36 & 0.38 \\
\hline Proportion with Duration Longer than 365 Days & 0.04 & 0.08 & 0.08 \\
\hline \multicolumn{4}{|l|}{ Other: } \\
\hline Proportion being married & 0.50 & 0.66 & 0.75 \\
\hline Unemployment compensation (SEK / Day) & 492 & 445 & 377 \\
\hline Duration of benefit period & 274 & 258 & 240 \\
\hline \multicolumn{4}{|l|}{ Year of Beginning the First Unemployment } \\
\hline \multicolumn{4}{|l|}{ Spell: } \\
\hline 1991 & 0.2 & 0.23 & 0.22 \\
\hline 1992 & 0.23 & 0.21 & 0.19 \\
\hline 1993 & 0.2 & 0.16 & 0.17 \\
\hline 1994 & 0.14 & 0.17 & 0.16 \\
\hline 1995 & 0.1 & 0.12 & 0.13 \\
\hline 1996 & 0.12 & 0.11 & 0.13 \\
\hline Number of Observations: & 26,664 & 2,307 & 3,181 \\
\hline Number of Unemployment Spells: & 41,326 & 3,354 & 4,366 \\
\hline
\end{tabular}




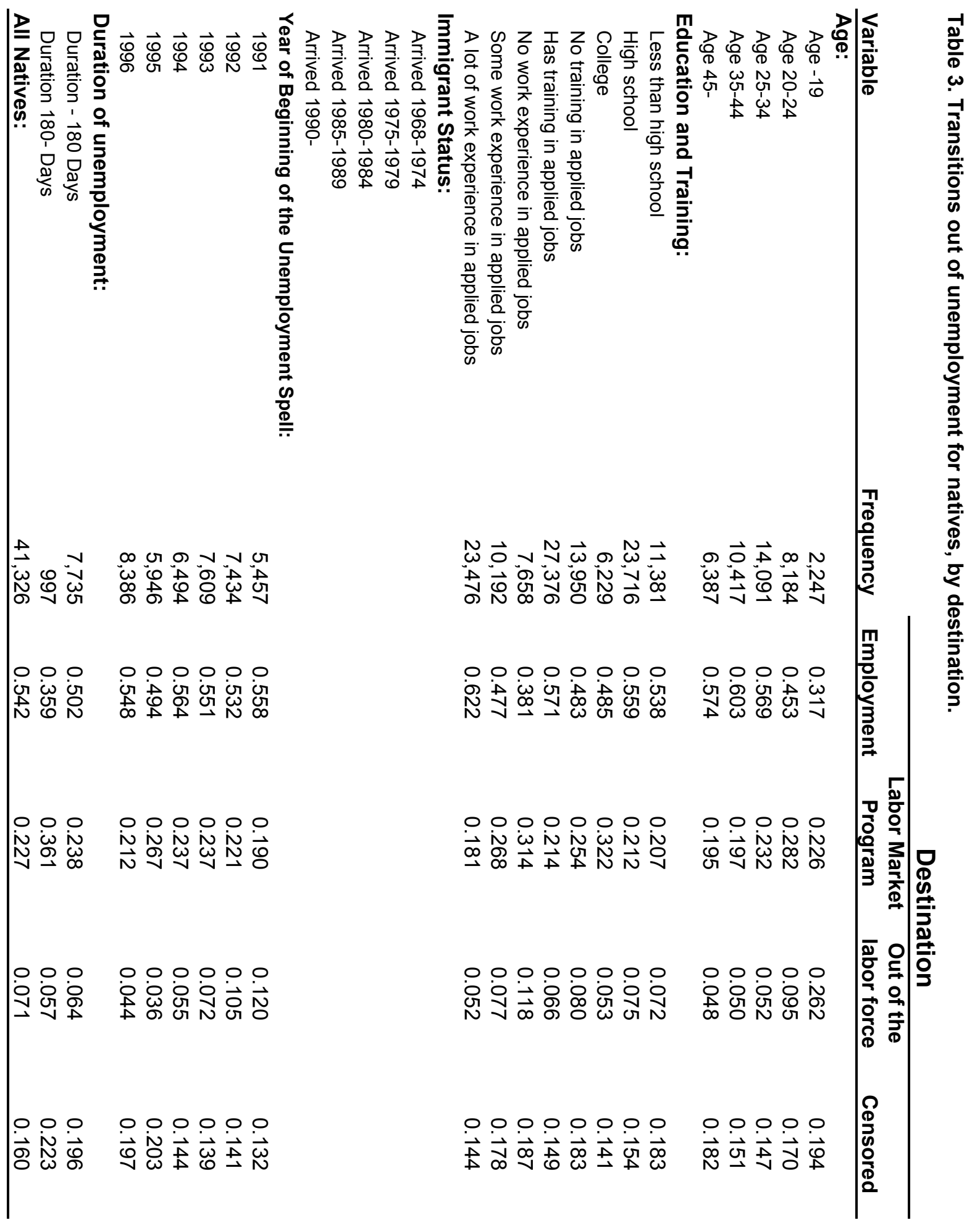




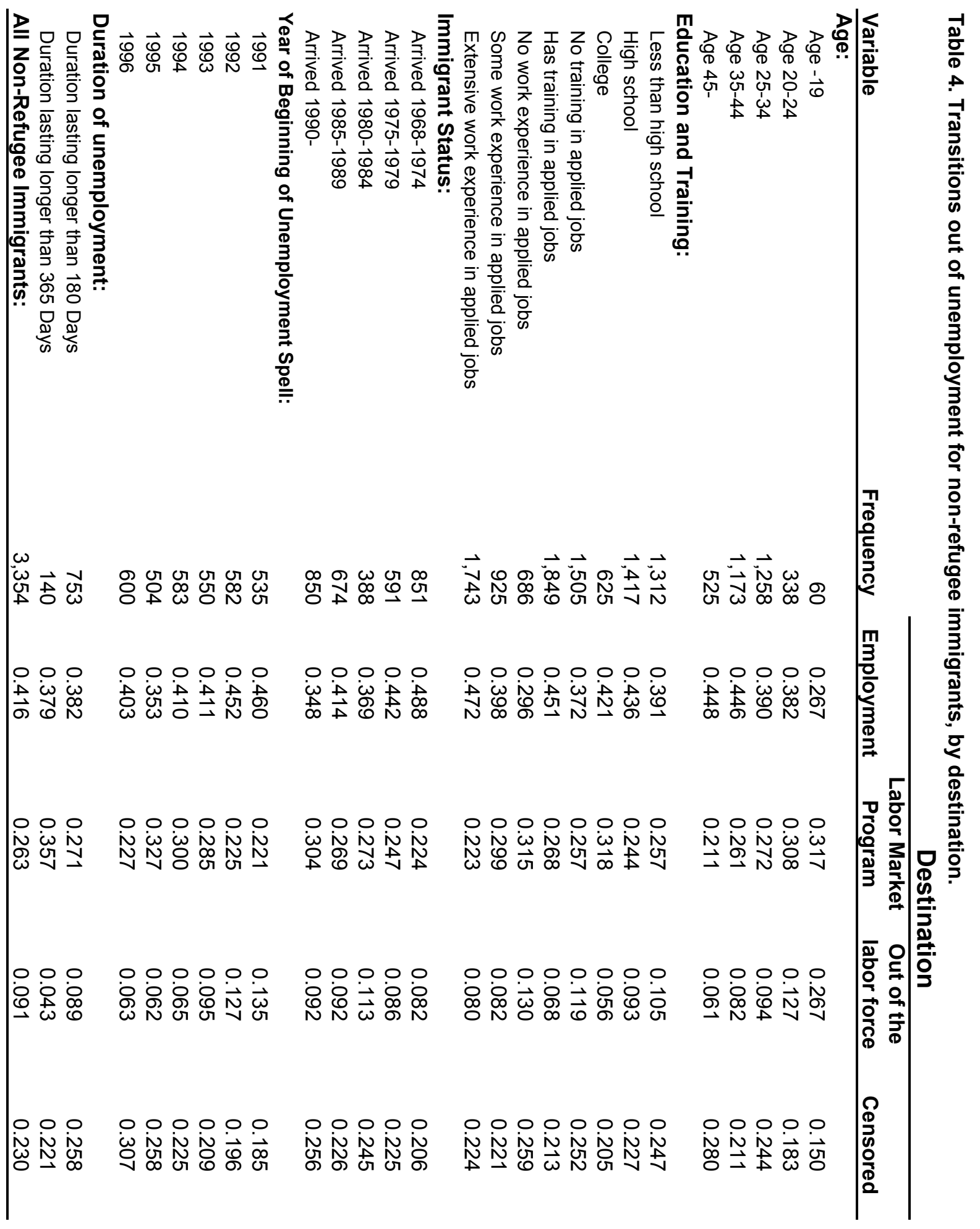




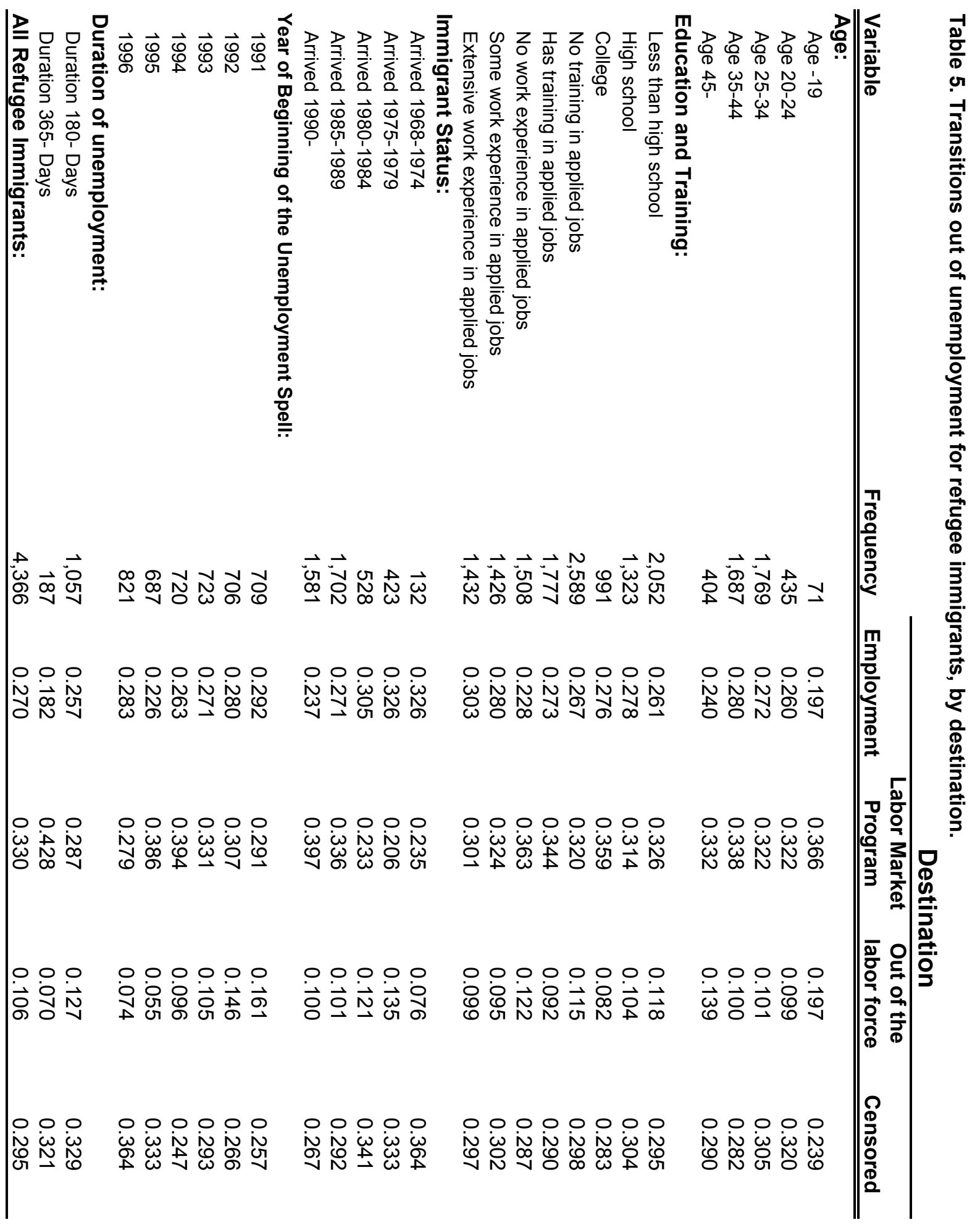




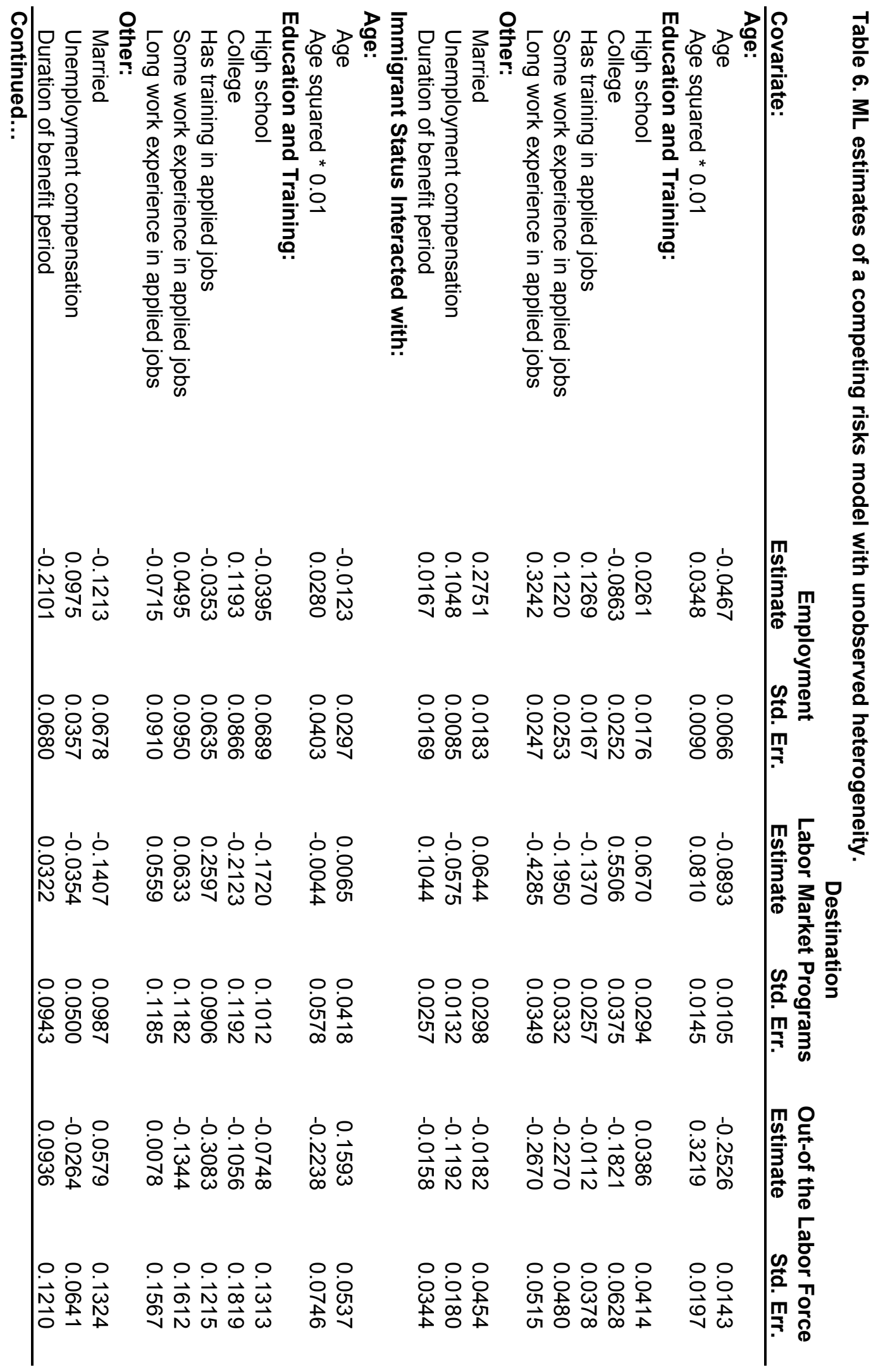




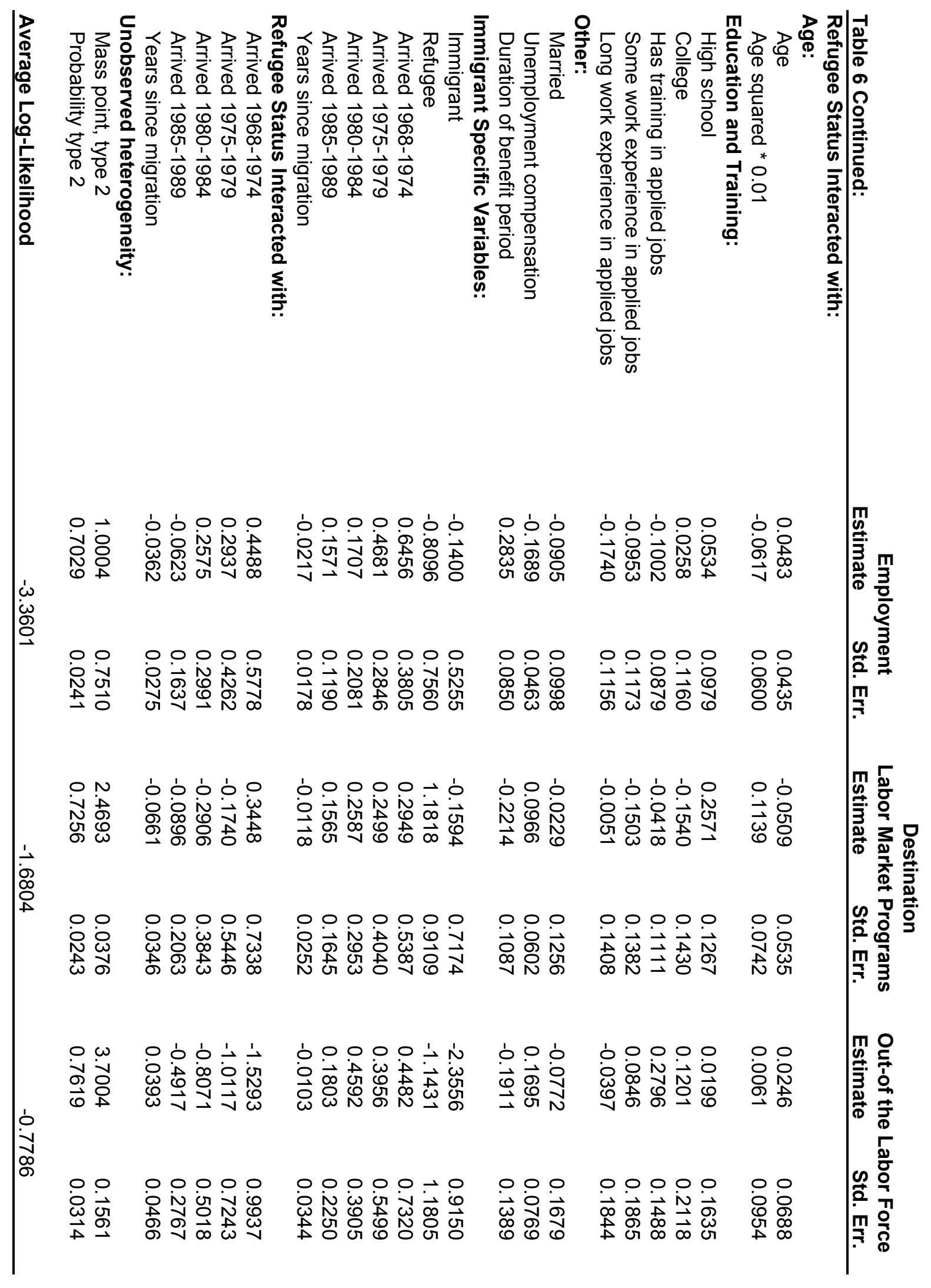


Table 7. Expected duration (in days) of unemployment spells.

Destination State:

\begin{tabular}{lccc} 
& Employment & $\begin{array}{c}\text { Labor Market } \\
\text { Program }\end{array}$ & $\begin{array}{c}\text { Out-of the } \\
\text { Labor Force }\end{array}$ \\
\hline \hline Representative Native & 81 & 237 & 635 \\
$\begin{array}{l}\text { Representative Non-Refugee } \\
\begin{array}{l}\text { Non-Refugee with the same attributes } \\
\text { as the representative native }\end{array}\end{array}$ & 108 & 233 & 592 \\
$\begin{array}{l}\text { Representative Refugee } \\
\begin{array}{l}\text { Refugee with the same attributes } \\
\text { as the representative native }\end{array}\end{array}$ & 167 & 225 & 591 \\
\hline
\end{tabular}

Note: The representative native was defined as having the average characteristics as reported

in Table 2 (modes for the binary variables). Further, it is assumed that the spell started in 1996.

The representative non-refugee and refugee was obtained in a similar way. 
Figure 1. Immigration into Sweden, Annual Inflow and Proportion of Population, 1940-1998.

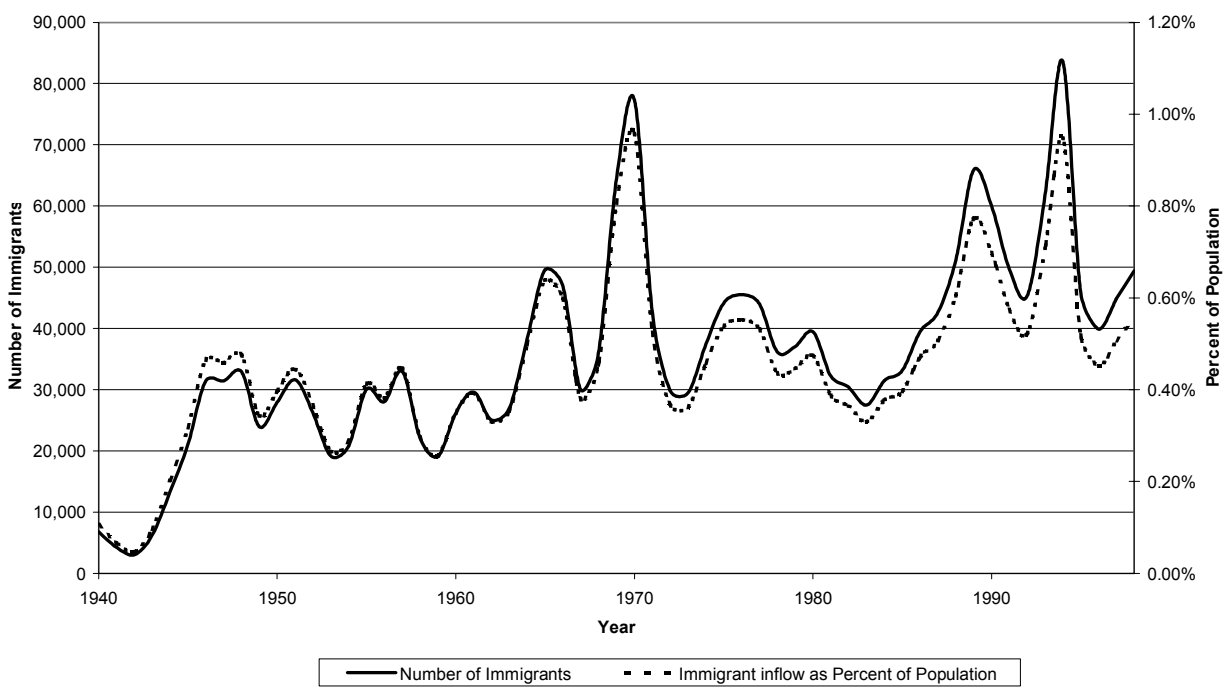

Figure 2. Average annual unemployment rates 1984-1998. Males and females aged 16-64.

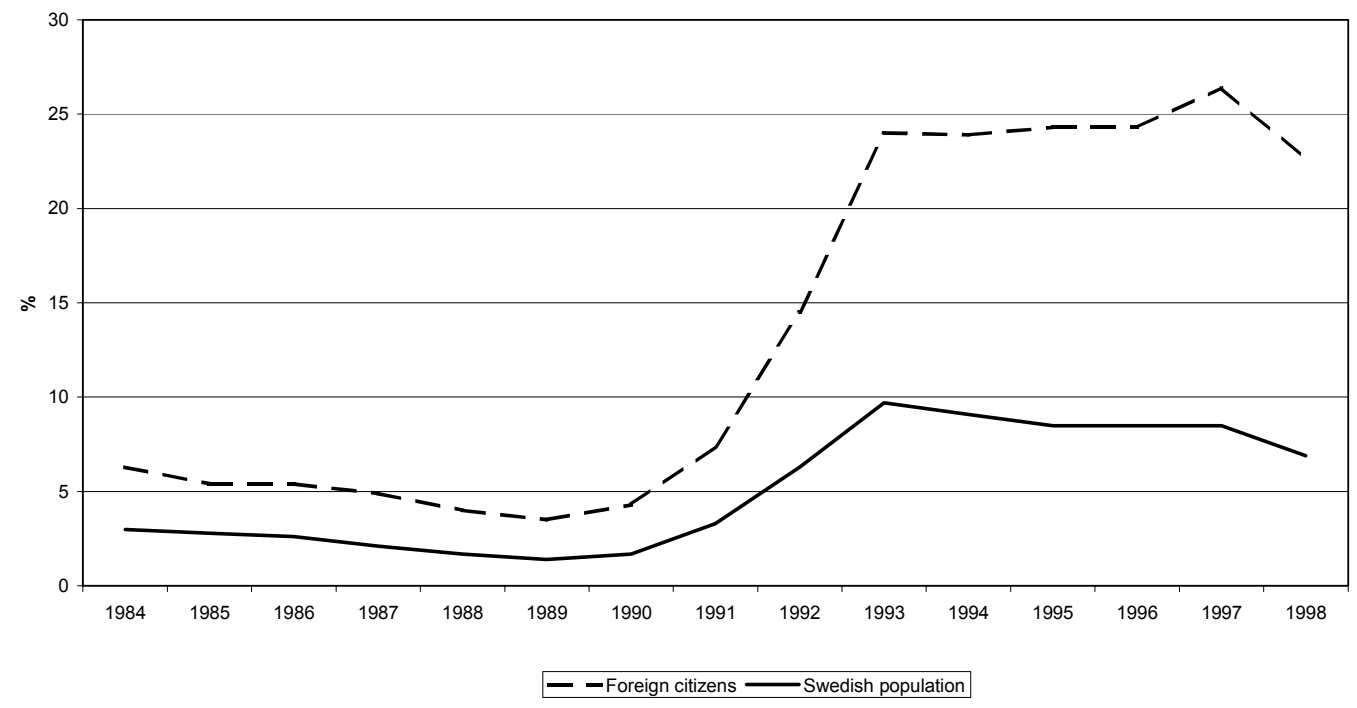

Sources: Labor Force Surveys by Statistics Sweden, 1984-1998. 


\section{IZA Discussion Papers}

No. Author(s)

51

A. Barrett

P. J. O'Connell

52 J. Mayer

R. T. Riphahn

53

J. Hartog

P. T. Pereira

J. A. C. Vieira

54 M. Lofstrom

55

L. Goerke

56

A. Lindbeck

D. J. Snower

57

I. N. Gang

K. F. Zimmermann

58

T. Bauer

K. F. Zimmermann

59

D. J. DeVoretz

S. A. Laryea

60

C. Belzil

J. Hansen

61

R. Winkelmann

62

A. Thalmaier

63

M. Ward

64

M. Ward

65

H. Lehmann

J. Wadsworth

A. Acquisti

66

E. J. Bird

H. Kayser

J. R. Frick

G. G. Wagner
Title

Area

Date

Does Training Generally Work?

5

$8 / 99$

The Returns to In-Company Training

Fertility Assimilation of Immigrants: Evidence

3

$8 / 99$

from Count Data Models

Inter-industry Wage Dispersion in Portugal: high

but falling

$8 / 99$

Labor Market Assimilation and the

$8 / 99$

Self-Employment Decision of Immigrant

Entrepreneurs

Value-added Tax versus Social Security

Contributions

Centralized Bargaining and Reorganized Work:

Are they compatible?

Is Child like Parent?

Educational Attainment and Ethnic Origin

9/99

Occupational Mobility of Ethnic Migrants

$9 / 99$

Canadian Immigration Experience:

Any Lessons for Europe?

Subjective Discount Rates, Intergenerational

Transfers and the Return to Schooling

Immigration: The New Zealand Experience

$10 / 99$

Bestimmungsgründe von Fehlzeiten: Welche

Rolle spielt die Arbeitslosigkeit?

1/2/3 9/99

6

$10 / 99$

Your Everyday, Average Academic

$10 / 99$

Salary and the Gender Salary Gap in the Academic Profession

Grime and Punishment: Job Insecurity and Wage 4

Arrears in the Russian Federation

$10 / 99$

The Immigrant Welfare Effect: Take-Up or

3

$10 / 99$ 

of Wage Differentials Transition Economies

\section{0 \\ J. C. van Ours}

J. Veenman
The Netherlands: Old Emigrants - Young Immigrant Country

Migration, Migrants and Policy in the United Kingdom

Privacy, time consistent optimal labor income taxation and education policy

Female Labour Supply, Flexibility of Working Hours, 1 and Job Mobility in the Netherlands

The Heterogeneity and Cyclical Sensitivity of 1 Unemployment: An Exploration of German Labor Market Flows 

Adversity

91 M. Lechner

Tenures that Shook the World: Worker Turnover in $\quad 4$ Russia, Poland and Britain

Identification and Estimation of Causal Effects of

An Evaluation of Public-Sector-Sponsored

Continuous Vocational Training Programs in East

N. Smith 
107 J. C. van Ours G. Ridder

J. Boone

J. C. van Ours

109 G. J. van den Berg

B. van der Klaauw

110 D. DeVoretz

C. Werner

111 V. Sorm

K. Terrell

L. Bellmann

T. Schank

113 R. Euwals

114 G. Brunello

A. Medio

115 A. Cigno

F. C. Rosati

116

C. Belzil

A. Haas

C. Klose

118 M. A. Shields

M. E. Ward

119 A. Lindbeck

D. J. Snower

120 P. T. Pereira

P. S. Martins

121 J. C. van Ours
Fast Track or Failure: A Study of the Completion

Rates of Graduate Students in Economics

Modeling Financial Incentives to Get Unemployed Back to Work

Combining Micro and Macro Unemployment

3

$1 / 00$

Duration Data

A Theory of Social Forces and Immigrant Second

1

$2 / 00$

Language Acquisition

Sectoral Restructuring and Labor Mobility:

A Comparative Look at the Czech Republic

Innovations, Wages and Demand for

5

$2 / 00$

Heterogeneous Labour: New Evidence from a

Matched Employer-Employee Data-Set

Do Mandatory Pensions Decrease Household

Savings? Evidence for the Netherlands

An Explanation of International Differences in

Education and Workplace Training

Why do Indian Children Work, and is it Bad for

3

$2 / 00$

Them?

Unemployment Insurance and Subsequent Job

3

$2 / 00$

Duration: Job Matching vs. Unobserved

Heterogeneity

IAB Employment Subsample 1975-1995.

Opportunities for Analysis Provided by the

Anonymised Subsample

Improving Nurse Retention in the British National

5

$2 / 00$

Health Service: The Impact of Job Satisfaction on Intentions to Quit

The Division of Labor and the Market for

Organizations

Does Education Reduce Wage Inequality?

5

Quantile Regressions Evidence from Fifteen

European Countries

Do Active Labor Market Policies Help Unemployed Workers to Find and Keep Regular Jobs? 
Rational Poverty or Poor Rationality? The Take-up of Social Assistance Benefits

125 F. Büchel

The Income Portfolio of Immigrants in Germany -

Effects of Ethnic Origin and Assimilation. Or:

J. R. Frick

126 J. Fersterer

R. Winter-Ebmer

Who Gains from Income Re-Distribution?

127 M. Karanassou

D. J. Snower

Smoking, Discount Rates, and Returns to

Education

Characteristics of Unemployment Dynamics: The

Chain Reaction Approach

128 O. Ashenfelter

D. Ashmore

O. Deschênes

Do Unemployment Insurance Recipients Actively

Seek Work? Evidence From Randomized Trials in

Four U.S. States

129 B. R. Chiswick

M. E. Hurst

C. Lucifora

The Employment, Unemployment and Unemployment Compensation Benefits of Immigrants

The Returns to Education in Italy: A New Look at the Evidence

Are Immigrants Favorably Self-Selected? An

134 A. D. Kugler

G. Saint-Paul

135 A. Barrett P. J. O'Connell

136 M. Bräuninger M. Pannenberg

Is There a Wage Premium for Returning Irish

Unemployment and Productivity Growth: An

Empirical Analysis within the Augmented Solow 
141 R. Hujer

M. Wellner

142

J. J. Dolado

F. Felgueroso

J. F. Jimeno

143 P. J. Luke

M. E. Schaffer

144 G. Saint-Paul

145 M.-S. Yun

146 T. K. Bauer

J. P. Haisken-DeNew

147 M. Belot

J. C. van Ours

148 L. Goerke

149 R. Lalive

J. C. van Ours

J. Zweimüller

150 J. DiNardo

K. F. Hallock

J.-St. Pischke

151 M. Ward

152 J. J. Dolado

F. Felgueroso

J. F. Jimeno

153 A. S. Kalwij

M. Gregory

154 Michael Gerfin Michael Lechner

155 J. Hansen
The Effects of Public Sector Sponsored Training on

Individual Employment Performance in East

Germany

Explaining Youth Labor Market Problems in Spain: 3

Crowding-Out, Institutions, or Technology Shifts?

Wage Determination in Russia: An Econometric

Investigation

Flexibility vs. Rigidity: Does Spain have the worst of 1 both Worlds?

Decomposition Analysis for a Binary Choice Model 7

$4 / 00$

Employer Learning and the Returns to Schooling

5

Does the Recent Success of Some OECD

Countries in Lowering their Unemployment Rates

Lie in the Clever Design of their Labour Market

Reforms?

Employment Effects of Labour Taxation in an Efficiency Wage Model with Alternative Budget

Constraints and Time Horizons

The Impact of Active Labor Market Programs and

Benefit Entitlement Rules on the Duration of Unemployment

Unions and the Labor Market for Managers

7

$5 / 00$

Gender, Salary and Promotion in the Academic Profession

The Role of the Minimum Wage in the Welfare 3

State: An Appraisal

$5 / 00$

Overtime Hours in Great Britain over the Period 3

$5 / 00$

1975-1999: A Panel Data Analysis

Microeconometric Evaluation of the Active Labour 6 Market Policy in Switzerland

The Duration of Immigrants' Unemployment Spells: $\quad 1 / 3$

Evidence from Sweden
$4 / 00$

$5 / 00$

$4 / 00$

$4 / 00$

$4 / 00$

$4 / 00$

$4 / 00$

$5 / 00$

$5 / 00$

$5 / 00$

$5 / 00$

An updated list of IZA Discussion Papers is available on the center's homepage www.iza.org. 